\title{
Age and Gender Differences in Job Opportunities
}

\author{
Stephan Humpert \\ Institute of Economics, \\ Leuphana University Lüneburg \\ Scharnhorststr. 1, 21335 Lüneburg, Germany \\ Tel: +49-4131-6772322 E-mail: humpert@ leuphana.de
}

Accepted: Feb 16, 2013 Published: March 05, 2013

Doi:10.5296/ijhrs.v3i1.3067

URL: http://dx.doi.org/10.5296/ijhrs.v3i1.3067

\begin{abstract}
There are only a few pieces of literature on age-specific occupational segregation. In this descriptive paper, I focus on occupational opportunities for newly-hired older male and female workers. This study is an enriched replication study of Hutchens (ILRR, 1988), who showed that firms employ older workers, but hire them less often than they hire younger ones. I use a rich dataset for West Germany with information covering almost thirty years, the regional file of the IAB Employment Sample (IABS-R04). By drawing segregation curves and calculating different measures, such as the Dissimilarity Index and the Hutchens Square Root Segregation Index, I find clear evidence that age-related segregation exists. While newly-hired workers in the age groups of 18 to 34 years and 35 to 54 years are quite similarly distributed in terms of the indices, those in the oldest age group, aged 55 years and above, and especially older women, are more segregated. Differences for older male and female workers over time may be explained by changes in labor and retirement policies.
\end{abstract}

Keywords: Labor Demand, Age Segregation, Older Workers, Gender

\section{Introduction}

There has been broad discussion on the demand for workers. In this context, occupational segregation is mostly discussed in terms of gender segregation, in works such as those of Blau and Hendricks (1979) and Anker (1997). The problem of age-specific segregation is discussed less. Only some newer surveys, such as those by Heywood and Siebert (2009), O'Brian (2010), and Backes-Gellner and Schneider (2012), give an overview. But at a time when societies, such as that of Germany, are ageing, the employability of older individuals is more and more relevant: see, for instance, Fuchs et al. (2011) for German labor force projections for the year 2050. Fuchs et al. calculate the increasing employment rates of the highest age groups in the potential workforce.

In this paper I focus on occupational opportunities for older male and female workers. This study is an enriched replication study of Hutchens (1988), who showed, for the United States, that firms employ older workers, but hire them less often than they hire younger ones. These findings are also variously shown by Del Rio and Alonso-Villar (2010) (Spain), Dixon (2009) 
(New Zealand), Dygalo (2007) (France), Hirsch et al. (2000) (US), Heywood et al. (1999) (Hong Kong), and Ilmakunnas and Ilmakunnas (2012) (Finland). I use a rich dataset for West Germany: the regional file of the IAB Employment Sample (IABS-R04), a panel of cross-sections for the years 1975 to 2004.

To measure the occupational segregation of newly-hired workers, I use different types of segregation curves and indices, such as the Duncan or Dissimilarity Index (Duncan and Duncan 1955) and the Hutchens Square Root Segregation Index (Hutchens 2001, 2004). I show a long-term decline in occupational segregation in Western Germany. While newly-hired male and female workers in the age groups of 18 to 34 years and 35 to 54 years are quite similarly distributed in terms of the indices, the oldest age group, those of 55 and above, is different. I find rising segregation beginning in the early 1980s and continuing until the late 1990s and the early years of this century. In the middle of the 1980s, the late 1990s and the early years of this century in particular, there were great structural changes in labor and retirement policies in Germany. These changes may have had different effects on the occupational segregation of older people. The effect of occupational segregation seems to be stronger for older women than for older men.

The rest of the paper is structured as follows. In the next section I review the literature. Section 3 summarizes different measures of occupational segregation. Section 4 presents a description of the data and empirical results for Germany, based on the regional file of the IAB Employment Sample (IABS-R04). The paper concludes, in Section 5, with a summary and a discussion of the findings.

\section{Theory and Literature Review}

\subsection{Demand for older Workers}

I argue that an individual's range of job opportunities theoretically shrinks with age. While younger worker have a wide range of jobs to choose from, older workers' choices are limited. The demand for older workers is lower than that for younger ones. This difference in employability is based on productivity aspects such as skills, and maybe on some kind of discrimination. Oi (1962) shows that the hiring of new workers is associated with quasi-fixed employment costs. These are the costs of the recruitment processes, and, later on, the costs of training activities for newly-hired workers. While specific training is given by a firm to strengthen skills related to the firm, general training increases the worker's own productivity more independently of the firm's specific needs. Becker (1962) discusses whether specific training is more often given to younger workers than to older ones. The younger ones will stay for more years with a firm, on average, than the older ones, and the hiring firm gets higher returns, such as increased productivity. In the case of general training, this is indirectly paid for by the worker, generally by the worker accepting lower wages. Hutchens (1988) argues that, because of the different payoff times discussed above, both types of training are more attractive for younger workers than for older ones.

Lazear $(1979,1981)$ demonstrates that firms are interested in paying deferred compensation. Here, newly-hired workers receive wages that are below the value of the marginal product at the beginning, and above the value of the marginal product at the end, of their careers with the firm. As a result, older job-holders with a long duration of tenure get high wages. Rising 
wage profiles ensure that workers are motivated and these profiles therefore save monitoring costs. On the one hand, jobs are protected for older workers within firms. On the other hand, firms have less motivation to hire older workers, rather than younger ones, from outside. Hutchens (1986) suggests that delayed payments can also be interpreted as fixed costs. Firms may see a chance to cheat on their workers by terminating their contracts earlier than expected by the workers. So firms have to pay a premium on the wage to compensate the workers for the hypothetical risk of being cheated. Pfeifer (2009) shows that if wages were paid in an equitable way, newly-hired older workers would be overpaid or under-productive. Zwick (2012) presents empirical evidence that firms with step profiles for seniority wages hire older workers less often, and prefer candidates with fewer years of working experience. Hutchen (2007) discuss that jobs with specific need of several years of experience should be highly replaced with older and experienced workers from the outside. But he presents evidence that internal solutions such as hiring from internal labor markets are more often the case.

\subsection{Literature Review}

Hutchens (1988) computes segregation curves to show that new entrants aged over 55 have fewer occupational opportunities than entrants aged between 24 and 35 . US data from the National Longitudinal Survey (NLS) for 1983 shows that incumbents aged 55 years or above are more equally distributed among occupations than newly-hired people in that age group. Hutchens (1986) composes an Opportunity Index ${ }^{1}$ to measure the hiring opportunities for older workers. Using the US data from the NLS for 1970 for men, the Opportunity Index for hiring workers above the age of 55 is used as an independent variable in regressions for aspects such as pensions and mandatory retirement. Because of the fixed costs of employment, older individuals face a lower probability of being hired than younger ones. Hutchens (1993) uses the Survey of Displaced Workers, a supplement to the Current Population Survey (CPS), for the years from 1983 to 1988. This includes information about male workers aged between 39 and 59 years who have suffered from a plant closure in the previous five years. Using the Opportunity Index, there is evidence that older displaced workers face a lower probability of finding an occupation in a different sector than do younger workers. ${ }^{2}$

Scott et al. (1995) use matched data from US Enterprise and Establishment Microdata 1991 (USEEM) and four waves of the Employee Benefits Supplement based on the CPS 1979 to 1993. They show that firms' health insurance policies may influence their hiring decisions. Firms which make higher health insurance offers employ more older workers, but hire fewer. Heywood et al. (1999) use cross-section data for 1996 for the case of Hong Kong. As a central result, the requirement by firms that candidates have certain skills lowers the probability that older individuals will be hired. This is a special case, because the age of 35 is used here to split workers into 'young' and 'old', and Hong Kong has no anti-discrimination law concerning age. Hirsch et al. (2000) use CPS data for the years 1983 to 1995. They compute segregation curves and Gini coefficients to show that there is no increase in segregation over time for workers above the age of 50. Newly-hired older women are less

Here the proportion of recently hired older workers is divided by the proportion of all workers above the age of 55 . Hutchens $(1993,102)$ argues that "(t)he index used here may have substantially more noise than signal". 
unequally distributed among occupations than newly-hired older men. Additionally, Hirsch et al. give empirical evidence that older workers have less access to occupations with on-the-job training and specific skill needs, such as computer use. But there are only weak results concerning working conditions, such as heavy lifting.

In a research note, Dygalo (2007) uses a long French series of employer-employee data, the Déclarations annuelles des salaires (DADS), for the years 1976 to 1996. She computes segregation curves and Hutchens Square Root Segregation Indices. Comparing newly-hired workers above the age of 55, there is an unequal distribution between workers who have formerly been unemployed for more than a year and those who have been unemployed for a shorter period. This may be interpreted as an age-related decline in occupational opportunities, based on unemployment duration between two types of occupation. Dixon (2009) uses linked employer-employee data (LEED) for New Zealand to compute the Opportunity Index for the years 2004 to 2007 . This statistical report presents industry patterns in relation to recruiting older workers. Workers in the highest age group of 70 to 74 years are mostly hired in the education sector. Del Rio and Alonso-Villar (2010) present age- and gender-related occupational segregation information for the case of Spain. They use data from the Spanish Current Population Survey (EPS) for 2007 to compute segregation curves and different measures of segregation, such as the Mutual Information Index and the unbounded Gini coefficient. Workers above the age of 45 years are more segregated than those in all the younger age groups, and older women have fewer occupational opportunities than older men. Ilmakunnas and Ilmakunnas (2012) use a long Finnish series of linked employer-employee data for the years 1990 to 2004 to compute segregation curves and Gini coefficients. Workers aged 50 and above leave firms much more often than they enter them. The authors compare the Gini coefficients over time, and find stable values for exits and mixed results for hires. While from 1990 to 2000 age segregation rose, the Gini coefficients for the later years are stable.

Chan and Stevens (2001) use US data from the Health and Retirement Study (HRS) 1992 to 1996 to show that older individuals have low probabilities of being re-employed after losing their jobs. They compute a gap in employment rates of about 20 per cent between displaced and non-displaced workers. Adams (2004) finds a negative but not significant effect of the anti-age discrimination laws on the hiring probabilities for older workers in the US. He uses CPS data from 1960 to 1967 with difference-in-differences estimations to evaluate the effect of variation in the legislation of federal states.

Adams and Heywood (2007) use information from the Australian Workplace Industrial Relations Survey (AWIRS) for 1995. They present a negative effect of a rising tenure-wage ratio on the probability of hiring older workers. Using UK data from the Workplace Employment Relations Survey (WERS) for 1998, Daniel and Heywood (2007) discuss the importance of steeper wage profiles based on seniority, and internal labor markets, for lower recruitment of older workers. Adler and Hilber (2009) use US Longitudinal Employer-Household Dynamics data (LEHD) for 2005 to analyze the employment patterns of older workers. They show that older workers who have to change their employers try to select firms which employ a high share of older workers and participate in a growing sector.

Heywood et al. (2010) use German data from the Hanover Firm Panel for 2002 to analyze the 
hiring preferences of job searchers over the age of 50. There is evidence of the importance of skills and the existence of internal labor markets, both of which lower the probability that older individuals will be hired. Zwick (2012) uses German linked employer-employee data (LIAB) to analyze different deferred compensation schemes. The Opportunity Index and the share of newly-hired women over the age of 50 are used to show that firms with stronger deferred compensation schemes hire more younger men than younger women. But these firms do not hire fewer older women than older men. Humpert and Pfeifer (2013) use the German Socio Economic Panel Study (SOEP) for 2007 and 2008 to show that older male and female workers, and mothers, have higher reservation wages and a higher preference for leisure, which can explain lower employment rates in these groups in Germany.

Vandenberghe (2011) and Pfeifer and Wagner (2012) compute age- and gender-related productivity profiles. ${ }^{3}$ In the case of Belgian firms, Vandenberghe (2011) shows that older women are less likely to be employed than younger women, or men of any age, because of lower productivity. This age- and gender-specific lack of productivity may not be compensated for by a lower labor cost, such as lower wages or lower social security payments. Pfeifer and Wagner (2012) show that, for Germany, firms with higher shares of female workers do not automatically have lower profitability than firms with lower shares. With a new type of dataset, they report higher profitability for these firms. They conclude that the lower productivity of women may be over-compensated for by lower wage costs.

\section{Measurement of Occupational Segregation}

In the literature on segregation there is a broad discussion on proper measuring. Occupational segregation is mostly measured using indices scaled from zero to one and visually using Lorenz curves or segregation curves. In general, both ways of measuring are used for measurements at one point in time. To compare segregation over time, a set of index points or an array of curves is needed. While income and GDP are scaled by ratio, occupations are nominally scaled ${ }^{4}$. They have to be ordered by their number of observations. Surveys like those of James and Taeuber (1985), Watts (1998) or Ransom (2000) show the historical development of the relevant indicators. The gold standard in measuring any segregation has for a long time been the Dissimilarity Index $D$ defined by Duncan and Duncan (1955). The Dissimilarity Index can be visually interpreted as the maximum distance between the equality line and a segregation curve. See equation (1) for $D$. Let the number of workers $i=1, \ldots, \mathrm{n}$ in an occupation be $p i$ for workers and $r_{i}$ for incumbents. $P$ represents the number of all newly-hired workers, and $R$ represents the number of incumbents.

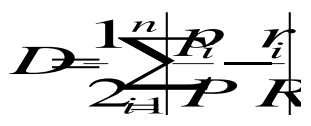

James and Taeuber (1985) show that the Gini coefficient $G$ is computed from the Lorenz or segregation curves. The Gini coefficient can be visualized as twice the area between the

While Koller and Gruber (2001), Bookmann and Zwick (2004), Lahey (2008), and Van Dalen et al. (2010) discuss whether older workers are rated to be less productive than younger ones, Bellman and Brussig (2007) show that older individuals also apply for jobs less often. Pfeiffer and Reuß (2008) show that, in general, cognitive skills increase until the age of 20, while self-regulatory skills increase until the age of 60 .

For example: A butcher is neither better nor worth more than a tailor. But the number of butchers in a given distribution may be higher or lower than the number of tailors. 
equality line and the curve. Both indices $D$ and $G$ are scaled from zero to one, where zero means equal, and one unequal, distribution. Hutchens (1991) argues that $D$ is not as sensitive as $G$ for occupational distributions. Hutchens (1988) himself computes segregation curves that take into account occupational specialties. This is a so-called RIMFO condition (relative inequality measure for occupation) of four characteristics of segregation measurement ${ }^{5}$. In a similar way to the well-established box illustration for Lorenz curves, equality is drawn with a continuous line from the origin $(0,0)$ to the upper right corner $(1,1)$. There are two extremes: no segregation and total segregation. In the first case, the segregation curve is identical to the equality line. In the second one, the curve is a triangle located in the lower right corner. Each hypothetical segregation curve would lie between these two extremes. On the left side Hutchens measures the cumulative percentage of Type 1 people and on the right side the cumulative percentage of Type 2 people. The so-called Type 1 people are newly-hired at an old age, and the Type 2 people represent the others which are already employed. While the original Lorenz curves work for numerated measurements such as income, segregation curves also work for rankings such as occupations. Only non-intersecting segregation curves can be interpreted in terms of statistical domination. If there are two curves, the upper one, which is closer to the equal distribution, dominates the other. While intersecting curves cannot be interpreted in terms of dominance, indices can. A higher value for the index shows a higher degree of segregation.

Because of the ambiguous results of intersecting curves, Hutchens $(2001,2004)$ develops the so called Hutchens Square Root Segregation Index $H$. Again the $H$ index is scaled from zero to one, where zero means no segregation and one means total segregation. This measure additionally allows for the additive decomposition of segregation. See equation (2) for $H$. Let the number of workers $i=1, \ldots, \mathrm{n}$ in an occupation be $p i$ for newly-hired workers and $r$ for

incumbents. $P$ represents the number of all newly-hired workers, and $R$ represents the number of all incumbents.

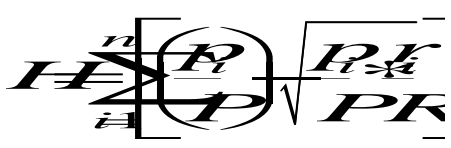

In contrast to the other, more common, ways of measuring segregation which are discussed above, this $H$ index not only fulfills the requirements of the four characteristics, but it also satisfies a set of seven properties which should be held by a good measure of occupational segregation ${ }^{6}$. So I am more in favor of this more elaborated measure, but in fact I use both of them and compare the results in the next section.

\section{Data and Results: IAB Employment Sample 1975-2004}

\subsection{Data}

For the analysis of the long-term developments in age-specific occupational segregation in Western Germany, I use the regional file of the IAB Employment Sample (IABS-R04), a

\footnotetext{
Hutchens (1991) first uses only three characteristic for the RIMFO measure (invariance of scale, symmetry and movement between groups), but he later (Hutchens (2001) adds a fourth characteristic (intensity of proportional divisions). Hutchens (2004) entitles the last three characteristics additive decomposability, symmetry in types and range. However, Hutchens (2012) discusses whether different occupational statuses and hierarchies should be part of the measure. To perform the index, I use a Stata ado file computed by Jenkins (2006).
} 
dataset provided by the German Federal Employment Agency. This gives information for the years 1975 to 2004 on a daily basis. It is a $2 \%$ random sample based on the administrative data of the German social security system. The data includes the working careers of more than 1.36 million individuals, with about 25 million observations. These are working people covered by the social security legislation and unemployed people who receive public unemployment benefits. Furthermore, there is detailed information for $130^{7}$ different types of occupations and 16 economic sectors. I look at the beginning and ending of employment and unemployment spells, gender, birth year, income, and educational information. A much more detailed description of the dataset is given by Drews (2008).

I start by limiting the data to 129 occupations, because of insecure information in a residual category of non-agricultural family assistants and others. Second, I use only individuals who are working on the cutoff date of $30^{\text {th }}$ June of every year $^{8}$. I only use workers covered by social security who work full-time or part-time, and individuals on apprenticeships, but I ignore the marginally employed, who have been included in the data set since 1999. Before 1999 trainees, individuals in partial retirement and working students were treated as general workers who were covered by social security legislation (in German: sozialversicherungspflichtige Beschäftigte ohne besondere Merkmale).

Although Eastern Germany has been included since 1992, I focus only on Western Germany. This is because, first of all, I am interested in the long-term effects over almost thirty years, and second because there are still different labor market conditions in the two former German states. ${ }^{9}$ To identify pure West German workers I follow the papers of Bachmann and Burda (2010) and Wichert and Wilke (2012), and exclude every person who has ever worked in Eastern Germany ${ }^{10}$. I am not able to differentiate clearly between workers from the former Eastern and the former Western parts of Berlin. So I exclude observations for the German capital as well. Because of missing retrospective employment information, I am first able to calculate occupational segregation for 1977. Using Stata routines described by Drews et al. (2007), I compute individual durations of tenure. In the next step I identify workers with less than or more than two years of tenure in a specific firm. Newly-hired workers have moved between occupations or have been unemployed in the previous two years. With this information I am able to draw segregation curves and indices based on occupations. The final dataset includes more that 11 million observations and about 425,000 people per year.

Table 1: Average Distributions - over Age and Gender (1977-2004)

\begin{tabular}{|c|c|c|c|c|c|}
\hline \multicolumn{5}{|c|}{ Men } \\
\hline $\begin{array}{c}\text { Age } \\
\text { Groups }\end{array}$ & $\begin{array}{c}\text { Number of } \\
\text { Observations }\end{array}$ & $\begin{array}{c}\text { Share of Jobs with } \\
\text { newly hired }\end{array}$ & $\begin{array}{c}\text { Number of } \\
\text { Occupations }\end{array}$ & $\begin{array}{c}\text { Duncan } \\
\text { Index }\end{array}$ & $\begin{array}{c}\text { Hutchens } \\
\text { Index }\end{array}$ \\
\hline
\end{tabular}

\footnotetext{
See Table A1 in the Appendix for the list of 130 jobs. These jobs are aggregated from the German system of job classifications of 1988 (Klassifikation der Berufe 1988).

Other surveys for Germany, such as that of Beblo et al. (2008), also use this cut-off date. Hutchens $(1988,1991,1993)$ and Hirsch et al. (2000) use CPS data with the cutoff date of $31^{\text {st }}$ January. I assume, however, that the summer season gives a more realistic picture of occupational opportunities.

See, for instance, Falk (2002) for a discussion of gender segregation in East and West Germany, and Kohn and Antoncyk (2011) for a broad discussion of the labor market effects of the German re-unification in 1990

${ }_{10}$ It is obvious that this is a strong assumption concerning internal migration. I tried weaker data classifications with similar results in terms of the long-term distributions of the Dissimilarity Indices and Hutchens Square Root Segregation Indices.
} 


\begin{tabular}{|c|c|c|c|c|c|}
\hline & & Workers & & & \\
\hline $18-34$ & $2,507,476$ & $1,113,936(44.44 \%)$ & 129 & 0.1264818 & 0.0138378 \\
\hline $35-54$ & $2,934,038$ & $538,740(18.36 \%)$ & 129 & 0.1608453 & 0.0192117 \\
\hline $55+$ & $1,145,817$ & $132,208(11.54 \%)$ & 129 & 0.1415790 & 0.0157255 \\
\hline All & $6,587,331$ & $\begin{array}{l}17,853,332 \\
(27.10 \%)\end{array}$ & 129 & 0.1367726 & 0.0165156 \\
\hline \multicolumn{6}{|c|}{ Women } \\
\hline $\begin{array}{c}\text { Age } \\
\text { Groups }\end{array}$ & $\begin{array}{c}\text { Number of } \\
\text { Observations }\end{array}$ & $\begin{array}{c}\text { Share of Jobs with } \\
\text { newly hired } \\
\text { Workers }\end{array}$ & $\begin{array}{l}\text { Number of } \\
\text { Occupations }\end{array}$ & $\begin{array}{l}\text { Duncan } \\
\text { Index }\end{array}$ & $\begin{array}{l}\text { Hutchens } \\
\text { Index }\end{array}$ \\
\hline $18-34$ & $2,018,446$ & $919,216(45.54 \%)$ & 129 & 0.1315002 & 0.0136558 \\
\hline $35-54$ & $2,000,687$ & $432,500(21.62 \%)$ & 129 & 0.1341335 & 0.0127952 \\
\hline $55+$ & 564,539 & $75,373(13.34 \%)$ & 129 & 0.1459089 & 0.0136454 \\
\hline All & $4,583,672$ & $1,426,998(31.13 \%)$ & 129 & 0.1242098 & 0.0116221 \\
\hline
\end{tabular}

Source: IABS 1975-2004.

It is known, from other datasets, that measurement errors in occupational information may exist: see, for instance, Kambourov and Manovskii (2008), and Rhein and Trübswetter (2012). Otherwise, because of the administrative origin and the tremendous sample size for the data, I do not suppose that I have any structural problems, such as recall biases. See Table 1 for a descriptive overview of newly-hired workers by age and gender.

I follow the ideas of Hutchens (2001, 2004), and present long-term developments in occupational segregation measured by the Dissimilarity Index and the Hutchens Square Root Segregation Index which are discussed above. Both indices are computed separately for three different age groups: the youngest group (those aged 18-34), the second group (those aged 35-54) and the oldest group (those aged 55 and above). I assume that these three groups represent a typical employment structure over the life cycle. Members of the first group will change their occupations more often than members of the others, because of information lags and early-life mismatches. Members of the second group will be more stable in their employment situation, because they will do less job-shopping than the younger people and maybe because their opportunities are more equal. For the last group I expect to find fewer occupational changes, but a higher occupational segregation. Table 2 shows examples of typical occupations for newly-hired older workers. ${ }^{11}$

\subsection{Empirical Results}

11 I know that some of these jobs are typical of seasonal or fixed-term work, such as security or cleaning jobs. 
From the perspective of the long-term development of occupational segregation in Western Germany, I compare different measures of segregation over the years 1977 to 2004. ${ }^{12}$ At first, I draw segregation curves for newly-hired workers. In Figure 1 I show segregation for men on the left hand side and segregation for women on the right. In general, segregation is higher for women than for men, and older women have the highest segregation. The curves do not intersect, so they can be interpreted in terms of domination. The curves for the youngest age groups are closest to the equality line, so segregation is the lowest. The curves for the middle age groups are similar to those for the younger, but the segregation is greater. For the oldest workers the curves are much more shaped, so the oldest age groups have the highest levels of segregation. In the second step I plot the Dissimilarity Index $D$ for men and women separately, to identify major trends in occupational segregation over the time span. In each of the figures I plot the smoothed value of the $D$ indices for the three age groups. The pattern of employment change differs with age and gender.

Figure 2 shows the distribution of occupations for men. While in the 1970s all age groups are far apart, from the 1990s onwards the groups seem to converge with each other. While the segregation curves present clear evidence that occupational segregation is highest for older workers, the pattern of the $D$ Index does not clearly prove this result for men. Most of the time, the middle age group has the lowest set of occupational opportunities. This might be a hint that the $D$ index is not sensitive enough for smaller observation groups such as the oldest age groups. Figure 3 shows the distribution of opportunities for women. The female distribution is different to the male one.

\begin{tabular}{|c|c|c|c|c|c|c|c|}
\hline \multicolumn{4}{|l|}{1980} & \multicolumn{4}{|l|}{2000} \\
\hline Male Jobs & Obs. & Female Jobs & Obs. & Male Jobs & Obs. & Female Jobs & Obs. \\
\hline $\begin{array}{l}\text { Motor vehicle } \\
\text { drivers }\end{array}$ & 510 & $\begin{array}{c}\text { Office } \\
\text { specialists }\end{array}$ & 598 & $\begin{array}{l}\text { Motor vehicle } \\
\text { drivers }\end{array}$ & 357 & $\begin{array}{l}\text { Household } \\
\text { cleaners }\end{array}$ & 548 \\
\hline $\begin{array}{c}\text { Office } \\
\text { specialists }\end{array}$ & 449 & $\begin{array}{l}\text { Household } \\
\text { cleaners }\end{array}$ & 592 & $\begin{array}{c}\text { Office } \\
\text { specialists }\end{array}$ & 311 & $\begin{array}{c}\text { Office } \\
\text { specialists }\end{array}$ & 499 \\
\hline $\begin{array}{c}\text { Entrepreneurs, } \\
\text { managing } \\
\text { directors,... }\end{array}$ & 375 & Salespersons & 573 & $\begin{array}{l}\text { Doormen, } \\
\text { caretakers }\end{array}$ & 219 & Salespersons & 346 \\
\hline $\begin{array}{l}\text { Warehouse } \\
\text { managers, } \\
\text { warehouse } \\
\text { men }\end{array}$ & 254 & $\begin{array}{l}\text { Stenographers, } \\
\text { shorthand-typis } \\
\text { ts, typists }\end{array}$ & 153 & $\begin{array}{c}\text { Stowers, } \\
\text { furniture } \\
\text { packers, ... }\end{array}$ & 200 & $\begin{array}{c}\text { Stenographers, } \\
\text { shorthand-typi } \\
\text { sts, typists }\end{array}$ & 90 \\
\hline Bricklayers & 229 & $\begin{array}{c}\text { Housekeeping } \\
\text { managers / }\end{array}$ & 159 & $\begin{array}{c}\text { Entrepreneurs, } \\
\text { managing }\end{array}$ & 192 & $\begin{array}{l}\text { Stowers, } \\
\text { furniture }\end{array}$ & 88 \\
\hline
\end{tabular}

12 For robustness checks, I tried the analysis with different randomly drawn sub-samples. The measures of segregation showed similar results. 


\begin{tabular}{|c|c|c|c|c|c|c|c|}
\hline & & $\begin{array}{l}\text { Consumer } \\
\text { adviser, ... }\end{array}$ & & directors, .... & & packers, ... & \\
\hline $\begin{array}{c}\text { Factory } \\
\text { guards, } \\
\text { detectives / } \\
\text { Watchmen, ... }\end{array}$ & 198 & $\begin{array}{c}\text { Cooks / } \\
\text { Ready-to-serve } \\
\text { meals, fruit, ... }\end{array}$ & 163 & $\begin{array}{c}\text { Factory guards, } \\
\text { detectives / } \\
\text { Watchmen, ... }\end{array}$ & 135 & $\begin{array}{c}\text { Housekeeping } \\
\text { managers / } \\
\text { Consumer } \\
\text { adviser, ... }\end{array}$ & 83 \\
\hline $\begin{array}{l}\text { Stowers, } \\
\text { furniture } \\
\text { packers, ... }\end{array}$ & 189 & $\begin{array}{l}\text { Packagers, } \\
\text { goods } \\
\text { receivers, } \\
\text { dispatchers }\end{array}$ & 78 & $\begin{array}{l}\text { Household } \\
\text { cleaners }\end{array}$ & 124 & $\begin{array}{c}\text { Cooks / } \\
\text { Ready-to-serv } \\
\text { e meals, } \\
\text { fruit,... }\end{array}$ & 70 \\
\hline $\begin{array}{l}\text { Building } \\
\text { laborer, } \\
\text { general }\end{array}$ & 183 & Accountants & 83 & $\begin{array}{c}\text { Other } \\
\text { technicians }\end{array}$ & 102 & $\begin{array}{c}\text { Social } \\
\text { workers, care } \\
\text { workers, ... }\end{array}$ & 65 \\
\hline Salespersons & 176 & $\begin{array}{l}\text { Nurses, } \\
\text { midwives }\end{array}$ & 54 & Salespersons & 101 & $\begin{array}{c}\text { Office } \\
\text { auxiliary } \\
\text { workers }\end{array}$ & 60 \\
\hline $\begin{array}{l}\text { Doormen, } \\
\text { caretakers }\end{array}$ & 152 & $\begin{array}{l}\text { Cutters / } \\
\text { Laundry } \\
\text { cutters, ... }\end{array}$ & 62 & $\begin{array}{l}\text { Commercial } \\
\text { agents, } \\
\text { travelers / } \\
\text { Mobile traders }\end{array}$ & 98 & Accountants & 48 \\
\hline
\end{tabular}
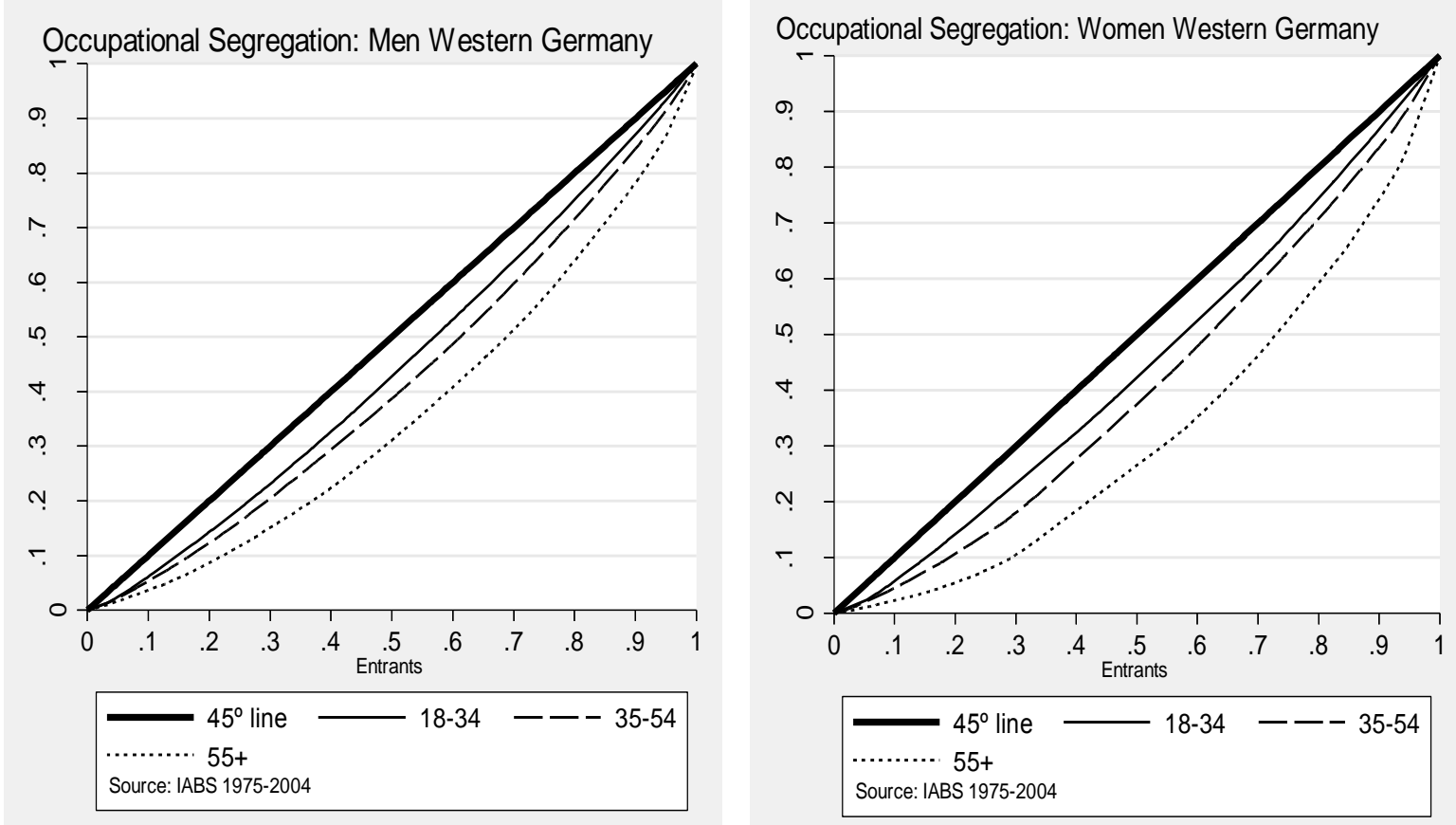
Figure 1: Segregation curves males and females (1977-2004, over all years)

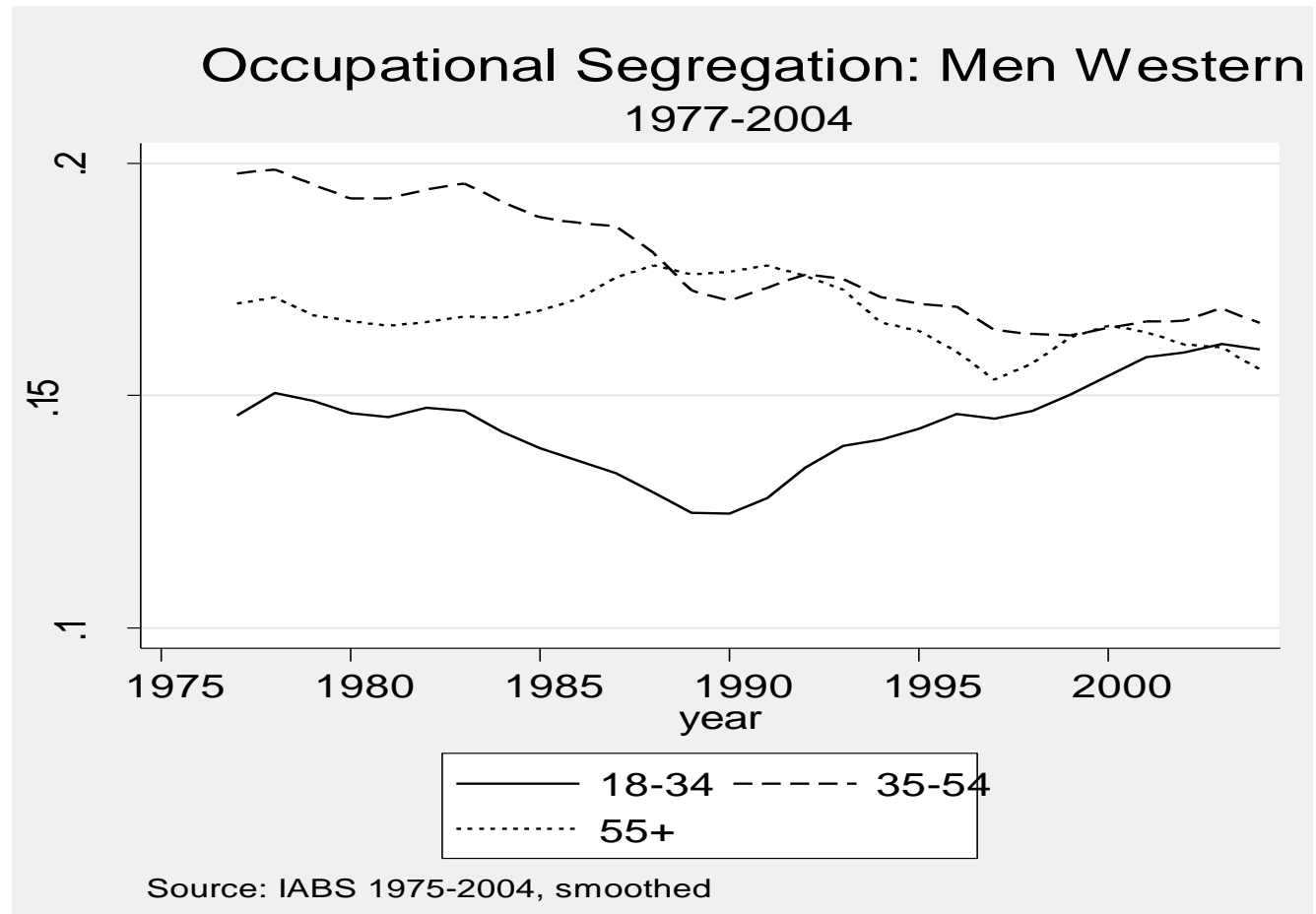

Figure 2: Duncan Index for West German men (smoothed by 5 years moving average)

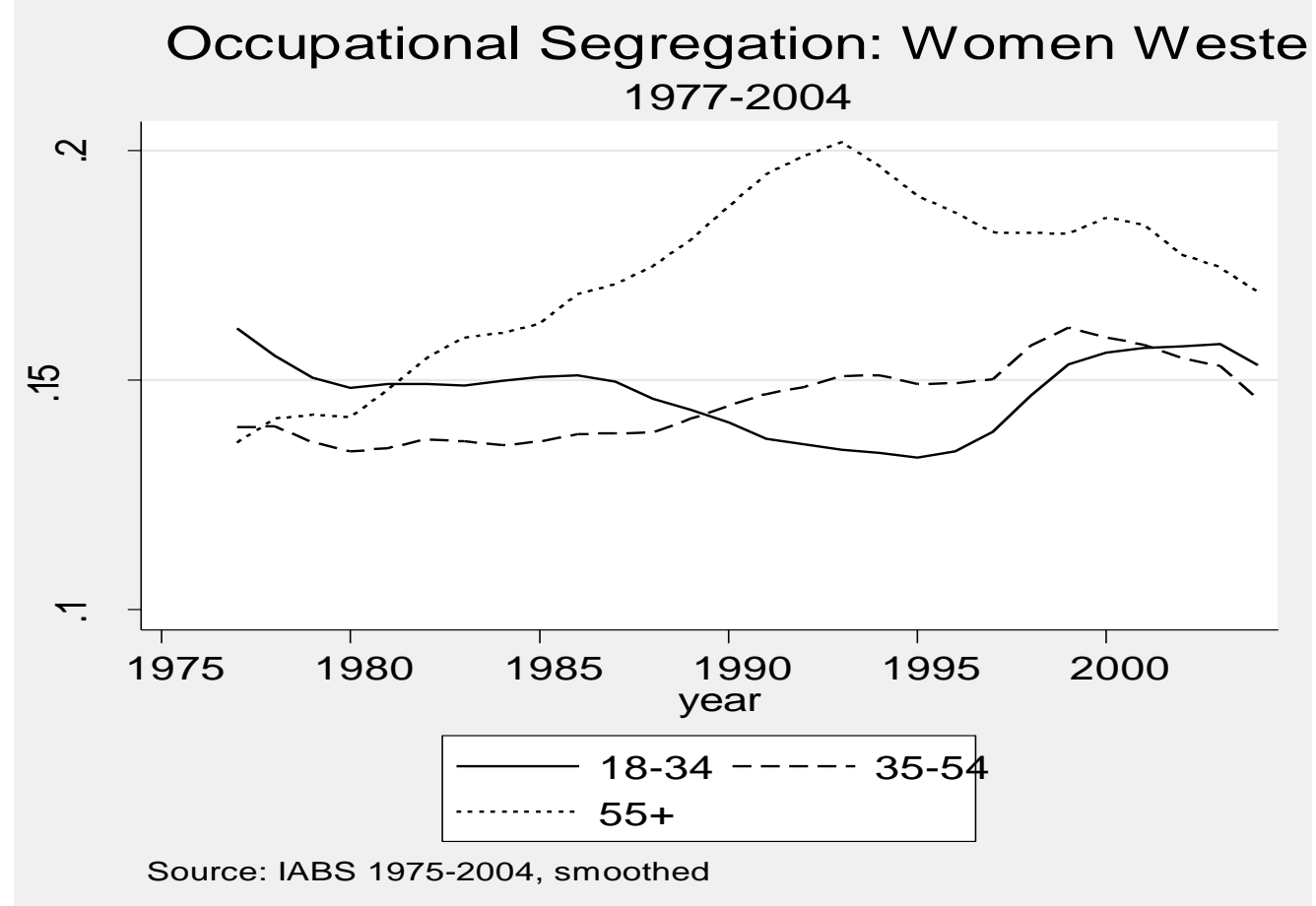

Figure 3: Duncan Index for West German women (smoothed by 5 years moving average)

There is a wider range of occupational segregation over time. Apart from in the 1990s, segregation of the youngest group is higher than that of the middle age group. Although in the 
1970s all age groups are close to each other, later they tend to grow apart, and they only converge slightly at the end of the time span. Until the early 1990s, the values of the $D$ Index increase for the oldest group of women. After this point in time, segregation declines. There is evidence that hiring older women tends to be a much bigger problem than hiring older men. The female results are close to those of other papers on German gender segregation. Beblo et al. (2008) decompose the Dissimilarity Index and show that declining gender segregation between 1996 and 2005 in Western Germany was driven by changes in occupational composition and gender composition. ${ }^{13}$

Because of these mixed results I present the Hutchens Square Root Segregation Index $H$ over the time span. The pattern of employment change differs with age and gender. Again I show separate figures for men and women, to identify major trends in occupational segregation over the time span. In each of the figures, I present the plotted value of the $H$ indices for the three age groups. Figure 4 shows the smoothed distribution of opportunities for men. While in the 1970s the age groups are all far apart, at the end of the time span the groups seem to converge with each other. The coefficients discussed in this section are taken from the original Hutchens Square Root Segregation Index $H$. The youngest age group, 18 to 34, has a slight increase from $1977(0.017)^{14}$ to $2004(0.020)$. The highest values are in the year 2000 (0.026) and the lowest values in 1987 (0.013) and 1990 (0.013). While the smallest values are in the late 1980s, there is a strong increase in the 1990s, with peaks in $1993(0.023), 1997$ (0.022) and 2000 (0.026). This shape can be described as slightly u-shaped. The $H$ index of middle-aged West German men declines considerably over time, from 0.030 in 1977 to 0.024 in 2004. After a peak in 1984 (0.032), occupational segregation declines until 1990 (0.019). With another slight increase after German unification, segregation tends to be stable. Beginning in the second half of the 1970s, the oldest age group has a slight decrease from 1977 (0.023) to 2004 (0.018). After a low in 1980 (0.019), segregation rises in the 1980s and the early 1990s. There are peaks in 1988 (0.030), 1992 (0.030), and $2000(0.039)$, with a temporary decline in 1998 (0.018). It is obvious that the oldest age group has a different shape from the others. Hiring of older workers seems to be much more sensitive towards the situation of younger workers.

\footnotetext{
13 Beblo et al. (2008) use linked employer-employee data (LIAB) for three different years with 290 occupations for each. They report that firms which are less segregated by gender employ higher shares of female, part-time, and more highly educated workers.

14 To interpret the values of the indices, it is less the size itself than the change over time that is important. This is in fact what Figures 2 to 5 show.
} 


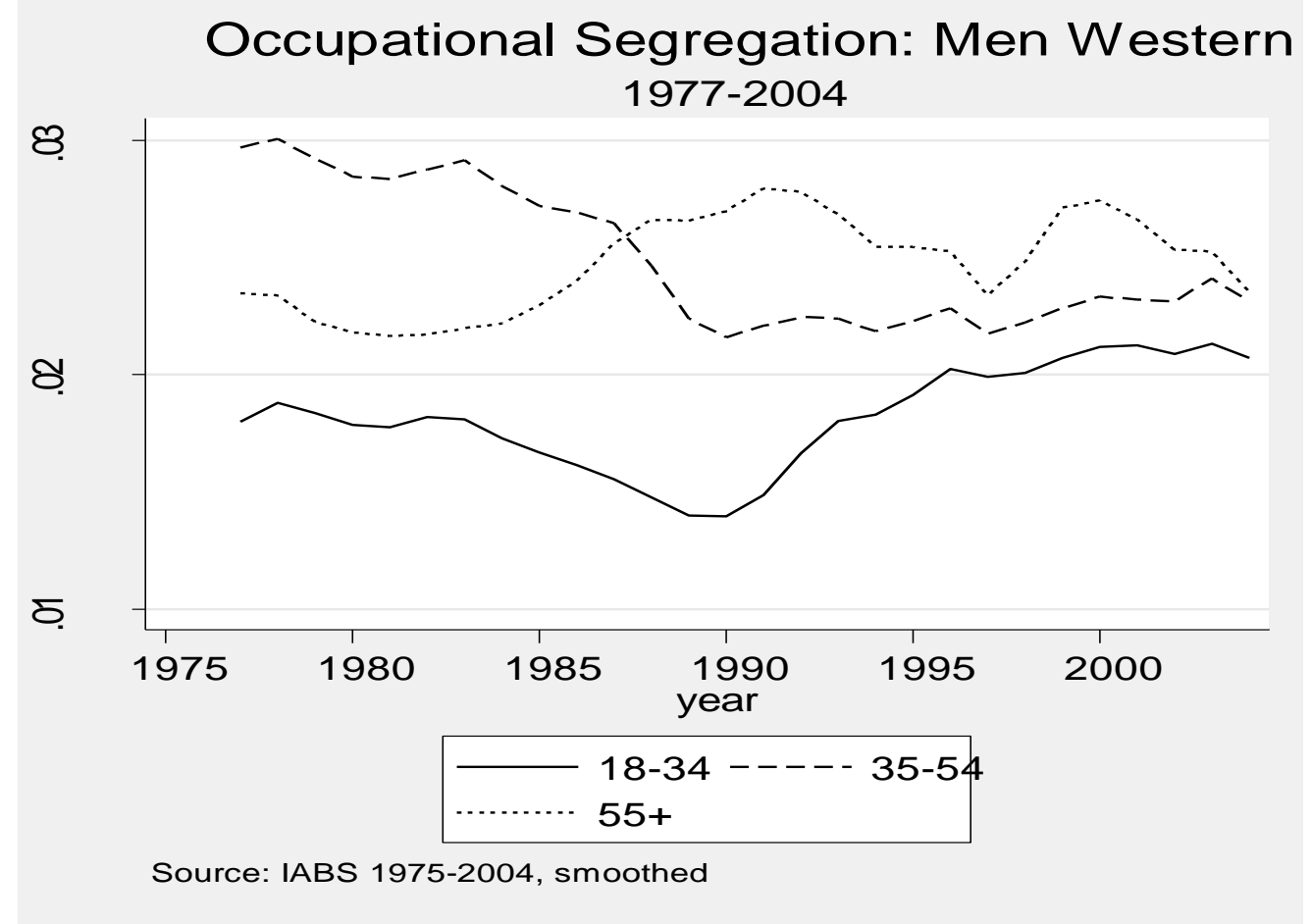

Figure 4: Hutchens Square Root Segregation Index for West German men (smoothed by 5 years moving average)

Figure 5 shows the distribution of opportunities for women. While in the 1970s all age groups are close to each other, later they tend to grow apart, and they only converge slightly at the end of the time span. In a similar way to the youngest males, the female group of those aged 18 to 34 has a slightly u-shaped profile over time. Starting with a first peak in 1977 (0.021), the values decline in two waves. The first low is in 1981 (0.015), and the second one in 1992 (0.012). Later, there is another increase in segregation, with two peaks, in 1997 (0.018) and in 1999 (0.026), and a decline until 2004 (0.018). In contrast to the men, the $H$ index of middle-aged West German women has a very different trend over time. From 1977 (0.013) to 2004 (0.015) there is a slight increase in segregation. Until 1987 (0.017), and with the index having its lowest value in 1980 (0.012), the middle-aged group is less segregated than the younger one. 


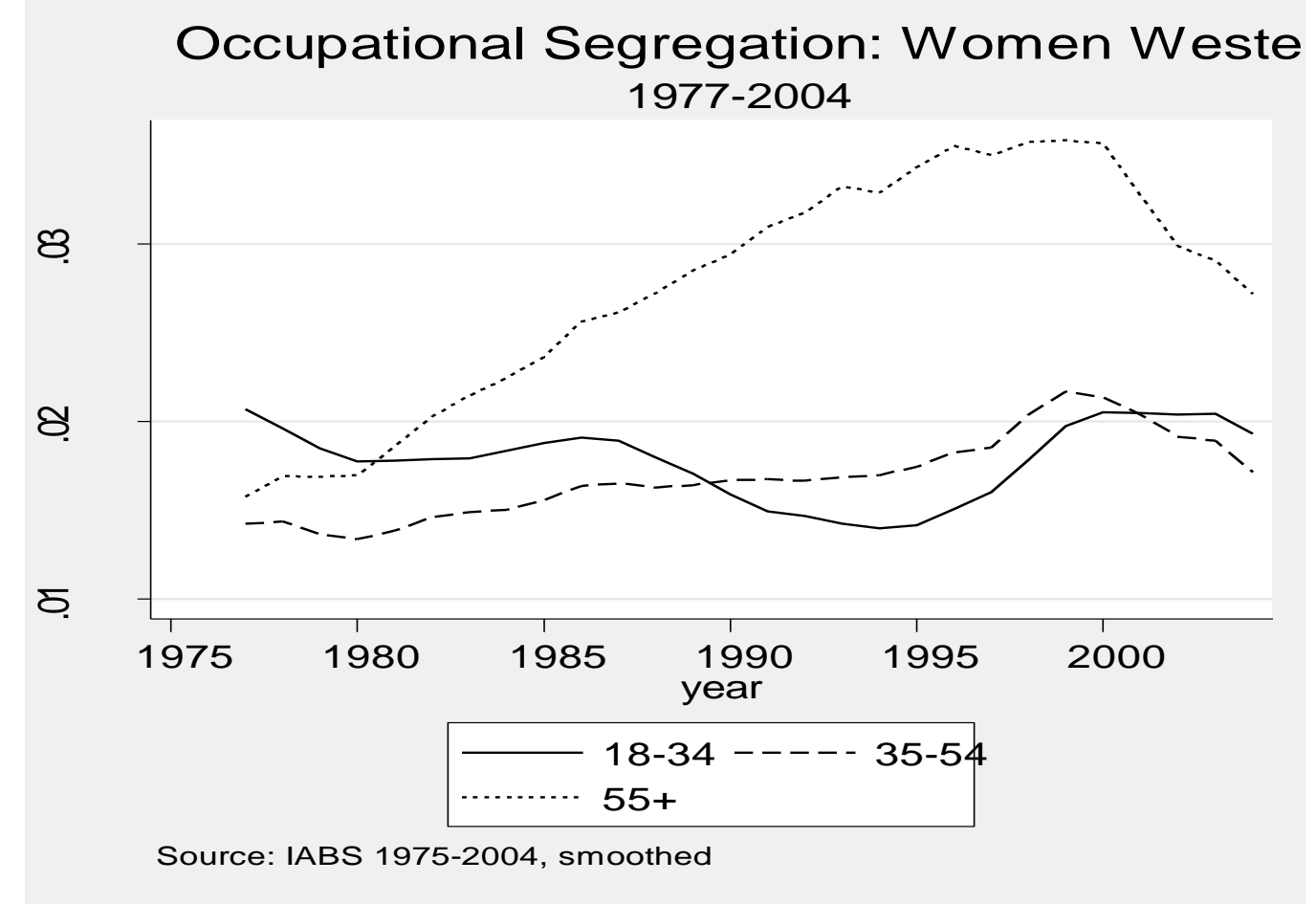

Figure 5: Hutchens Square Root Segregation Index for West German women (smoothed by 5 years moving average)

Then the two lines converge and run fairly parallel. I find a slight increase until the middle of the 1990s, and two peaks, in 1997 (0.022) and 1999 (0.028). After the millennium, segregation declines. The oldest age group has faced a rapid increase and strong fluctuations in occupational segregation over time. Starting at the minimum value in $1977(0.014)$, there is a nearly linear increase in the 1980s, with peaks in 1982 (0.027) and in 1990 (0.032). After temporary declines in 1991 (0.030) and 1995 (0.029), the highest measurements are in 1996 (0.041) and 2000 (0.040). After 2000, segregation of newly-hired older women hardly declines. It should be kept in mind that this group has the smallest number of observations, and its members do not always work in all of the 129 types of occupation. In some years there are only around 120 occupations in which female workers in this age group change their employment. As I discovered for the men, female segregation may also tend to converge.

The findings presented above are similar to other European results (Del Rio and Alonso-Villar (2010), Dygalo (2007), and Ilmakunnas and Ilmakunnas (2012)), but contrary to those for the US. There have always been fewer opportunities for older women than for older men in France and Spain, and increasing measures of segregation in the 1990s until the millennium in Finland. Hirsch et al. (2000) show no increase in old age segregation from the 1980s until the middle of the 1990s, and more equal distributions of older hired women than of older men.

Comparing the distributions of male and female workers over time, I detect some trends of convergence of gender-related segregation. In the youngest and middle age groups, women have a less segregated employment situation. In the oldest group, I find the opposite. Here female workers have much higher values of the $H$ index than male workers. Beginning in the 


\section{1) Macrothink}

International Journal of Human Resource Studies

ISSN 2162-3058

2013, Vol. 3, No. 1

second half of the 1990s, the indices for middle-aged workers run parallel. Before that time, the lines converged because the male index decreased and the female one increased. In the oldest group I find a parallel run of the lines, but a preceding increase in female segregation, beginning in the middle of the 1990s. The higher female occupational segregation for the oldest age group may be driven by increasing female employment rates over time. Men older than the age of 55 have traditionally higher employment rates than women of this age, but the rates for females have a stronger growth. The curves may be explained by changes in labor and retirement policies in Germany.

Table 3: Changes in German Social Policies over the Time Span

\begin{tabular}{|c|c|}
\hline Years: & Policy Changes: \\
\hline 1972 & Retirement age fixed at age 63, for handicapped people fixed at age 62 \\
\hline 1973 & Government stop the guest worker program started in 1955 "Anwerbestopp" \\
\hline 1977 & $\begin{array}{l}\text { New law on marriage (married women were allowed to work without husbands } \\
\text { permission) "Erstes Gesetz zur Reform des Ehe- und Familienrechts" }\end{array}$ \\
\hline 1980 & Retirement age for handicapped people lowered to age 60 \\
\hline 1983 & Law on support for returning guest workers "Rückkehrhilfegesetz" \\
\hline 1984 & Law on early retirement "Vorruhestandsgesetz" \\
\hline 1985 & $\begin{array}{l}\text { Law on employment promotion "Beschäftigungsförderungsgesetz" (Changes in } \\
1990 \text { and 1994) }\end{array}$ \\
\hline 1986 & $\begin{array}{l}\text { Law on child benefit and parental leave "Erziehungsgeldgesetz" (Changes in } \\
\text { 2004) }\end{array}$ \\
\hline 1989 & New law on early retirement "Altersteilzeitgesetz" \\
\hline 1992 & Pension reform \\
\hline 1992 & Retirement age increased to age 65 \\
\hline 1996 & $\begin{array}{l}\text { Retirement age for handicapped increased to age } 63 \text { and reforms on employment } \\
\text { promotion "Arbeitsrechtliches Beschäftigungsförderungsgesetz" }\end{array}$ \\
\hline 1997 & New reforms on employment promotion "Arbeitsförderungsreformgesetz" \\
\hline
\end{tabular}




\begin{tabular}{|c|c|}
\hline 1998 & $\begin{array}{l}\text { Third Book of the Social Code "3. Sozialgesetzbuch - SGB III" (collection of } \\
\text { former reforms on employment promotion) }\end{array}$ \\
\hline 1999 & Crucial monthly income level for marginal employment (level of $630 \mathrm{DM}$ ) \\
\hline 2001 & Pension reform \\
\hline 2001 & $\begin{array}{l}\text { Legal right of part-time employment and liberalization of fixed-term contracts } \\
\text { "Teilzeit- und Befristungsgesetz" }\end{array}$ \\
\hline 2002 & Law on job activation "Job AQTIV-Gesetz" \\
\hline $2003-$ & $\begin{array}{l}\text { Second Book of the Social Code "2. Sozialgesetzbuch - SGB II" (collection of } \\
\text { strong labor market reforms) }\end{array}$ \\
\hline 2003 & $\begin{array}{l}\text { Laws on labor market flexibility "1. Gesetz für moderne Dienstleistungen am } \\
\text { Arbeitsmarkt" (with liberalisation of temporary employment, but equal treatment), }\end{array}$ \\
\hline 2003 & $\begin{array}{l}\text { Laws on labor market flexibility " } 2 \text {. Gesetz für moderne Dienstleistungen am } \\
\text { Arbeitsmarkt" (with monthly income level for marginal employment ("Mini Job" } \\
\text { with } 400 \text { Euro, "Midi Job" with } 800 \text { Euro)) }\end{array}$ \\
\hline 2004 & $\begin{array}{l}\text { Law on labor market flexibility "3. Gesetz für moderne Dienstleistungen am } \\
\text { Arbeitsmarkt" }\end{array}$ \\
\hline 2005 & $\begin{array}{l}\text { Law on labor market flexibility " } 4 \text {. Gesetz für moderne Dienstleistungen am } \\
\text { Arbeitsmarkt" (with merge of unemployment benefits and social benefits to } \\
\text { „Arbeitslosengeld II“) }\end{array}$ \\
\hline 2007 & New law on parental benefit and parental leave "Elterngeld- und Elternzeitgesetz" \\
\hline
\end{tabular}

See Table 3 for a short overview of the relevant changes in the German labor and retirement laws. Maetzke and Ostner (2010) report an initial boost of gender equality in the 1960s and 1970s. Since oral contraceptives are legal available a sudden drop in birthrates happen.Under government of social-democratic chancellor Schmidt a reform on the law on marriages and divorce starts. The law of 1977 regulates that husband and wife should equally work at home and on the labor market. This means, inter alia, that a wife do not need any permission of her husband to outside the household. In the case of divorce the richer partner has to compensate the poorer one. 
Feil et al. (2008), and Eichhorst and Marx (2011) give an overview of the government of the christian-democratic chancellor Kohl. In the middle of the 1980s, the late 1990s and the early years of this century in particular, important structural changes happened in Germany. These changes may have had different effects on old age occupational segregation. On the one hand, early retirement was promoted by German politicians in 1984 and 1989, because of high unemployment rates. Early retirement schemes should lower the number of older workers on the labor market and may cause occupational segregation to decline, as long as the distribution between occupations does not change. On the other hand, in 1985 and more strongly by way of reforms in 1990 and 1994, politicians tried to deregulate the labor market by the introduction of part-time employment schemes and fixed-term contracts. The retirement age was increased in 1992 to take the pressure off the public pension system. These changes in policies should have increased the number of older workers and may have increased occupational segregation, as long as the distribution between occupations remained the same. In additional reforms in 1996 and 1997, employment promotions should have achieved more employment flexibility. Ostner (2010) discuss that the law on child benefit and parental leave from 1986 is an initial protection against dismissal for individuals on parental leave, especially for women. After the German unification in 1990 two different family policies have to be merged. While in West Germany a traditional male breadwinner model dominates, albeit a dual earner model in Eastern Germany.

Feil et al. (2008), and Eichhorst et. al (2010) present the structural changes of later government of social-democratic chancellor Schröder. In 1998, previous reforms on employment promotions were collected into the Third Book of the Social Code, SGB III. In 2001, individuals were given the legal right to change from full-time employment to part-time, and fixed-term contract regulations were brought in by the government. The Second Book of the Social Code, SGB II, was introduced from 2003 to 2005, to encourage unemployed individuals to return to work. Among other groups, older individuals could improve their skills by training, and find better jobs. Ostner (2010) shows that since 2002 family politics turn toward promotion of dual earner families and of early child education, e.g. by a new law on parental benefit and parental leave introduced in 2007.

These more flexible policies should increase the number of older workers and so make occupational segregation even higher. But this was not the case. Because of the great effects of implementing part-time work and fixed-term contracts, older workers may be distributed over a bigger set of occupations, and segregation should decline. If these considerations are true, then a policy of labor market flexibility has lowered occupational segregation for older workers in Germany.

\section{Conclusion}

The empirical literature on segregation is mostly on the topic of gender segregation. In this descriptive paper I turn to the questions of age and gender. Being inspired by the work of Robert Hutchens (1986, 1988, 2001, 2004), I focus on occupational segregation of newly-hired older workers in Western Germany.

I use the regional file of the IAB Employment Sample (IABS-R04), a rich dataset with information covering almost thirty years. Computing segregation curves and different indices, 
I plot figures for men and women for three different age groups (18-34, 35-54, and 55 and older). First of all, I can show that both age- and gender-specific segregation do exist in Germany. It is not only the difference between men and women, but also the difference between young and old, that plays a role in the range of employment opportunities. I compare the results of the Dissimilarity Indices and the Hutchens Square Root Segregation Indices, and find fairly similar results for the youngest and the middle-aged groups. While the $D$ Index shows age segregation only for the oldest women, the $H$ Index presents much clearer results. There is evidence for a long-term decline in occupational segregation for both genders in Western Germany. While the opportunities for men seem to converge for the three age groups, women are more segregated with age. The group of women over the age of 55, in particular, seems to face the greatest segregation in the labor market. While newly-hired male and female workers in the age groups of 18 to 34 and 35 to 54 have quite a similar distribution in terms of the indices, the group of workers older than 55 is different. Beginning in the 1980s, segregation for older male workers tended to rise until the early 1990s and to decline later. Around the late 1990s there was a temporary increase. For older female workers, the distribution I describe is similar, but stronger. Beginning in the 1980s, segregation rose until the middle of the 1990s. Later it tended to remain stable and it declined in the early years of this century.

My descriptive findings above are close to the literature for European countries (Del Rio and Alonso-Villar (2010), Dygalo (2007), and Ilmakunnas and Ilmakunnas (2012)), but contrary to that for the US (Hirsch et al. (2000)). There have always been fewer opportunities for older women than for older men in France and Spain, and increasing measures of segregation in the 1990s for Finland. As Vandenberghe (2011) shows, the special case of older women's employability may be based on a lack of productivity. Hirsch et al. (2000) show no increase in old age segregation from the 1980s until the middle of the 1990s, and more equal distributions of older hired women than of older men.

Both curves for the oldest age groups may be explained by changes in labor and retirement policies in Germany. In the middle of the 1980s, the late 1990s and the early years of this century, in particular, important structural changes occurred. While early retirement schemes were initially used to decrease the old age labor supply, later on, part-time employment and fixed-term contracts should have raised it. This shows that appropriate matching and better working conditions may help to increase employment opportunities even for older workers. So in the future, the participation of older workers in the labor market may be fostered by introducing more flexible working arrangements.

\section{Acknowledgement}

The work was financially supported by the VolkswagenStiftung. I thank Christian Pfeifer, Dirk Oberschachtsiek and Thomas Zwick, as well as participants of the Annual Meeting of the Austrian Economics Association 2012 in Vienna, the Colloquium in Personnel Economics 2012 in Paderborn, and of research seminars at Leuphana University Lüneburg and the NIW Hanover for their comments and discussions. 


\section{References}

Adams, Scott J. (2004). Age discrimination legislation and the employment of older workers. Labour Economics 11(2), 219-241

Adams, Scott J., Heywood, John S. (2007). The age of hiring and deferred compensation: Evidence from Australia. The Economic Record 83(261), 174-190

Adler, Geri, Hilber, Don (2009). Industry hiring patterns of older workers. Research on Aging 31(1), 69-88

Anker, Richard (1997). Theories of occupational segregation by sex: An overview. International Labor Review 136(3), 315-339

Bachmann, Ronald, Burda, Michael C. (2011). Sectoral transformation, turbulence and labor market dynamics in Germany. German Economic Review, 11(1), 37-59

Backes-Gellner, Uschi, Schneider, Martin R. (2012). Economic crisis and the elderly. Gerontology 58(2), 188-192

Beblo, Miriam, Heinze, Anja, Wolf, Elke (2008). Entwicklung der beruflichen Segregation von Männern und Frauen zwischen 1996 und 2005 - Eine Bestandsaufnahme auf betrieblicher Ebene. Zeitschrift für ArbeitsmarktForschung / Journal for Labour Market Research 41(2-3), 181-198

Becker, Gary S. (1962). Investment in human capital: A theoretical analysis. Journal of Political Economy 70(5) Part 2, 9-49

Bellmann, Lutz, Brussig, Martin (2007). Recruitment and job applications of older jobseekers from the establishments' perspective. IZA Discussion Paper 2721

Blau, Francis D., Hendricks, Wallace, E. (1979). Occupational segregation by sex: Trends and prospects. Journal of Human Resources 14(2), 197-210

Boockmann, Bernhard, Zwick, Thomas (2004). Betriebliche Determinanten der Beschäftigung älterer Arbeitnehmer. Zeitschrift für ArbeitsmarktForschung / Journal for Labour Market Research 37(1), 53-63.

Chan, Sewin, Stevens, Ann Huff (2001). Job loss and employment patterns of older workers. Journal of Labor Economics 19(2), 484-521

Daniel, Kirsten, Heywood, John S. (2007). The determinants of hiring older workers. UK evidence. Labour Economics 14(1), 35-51

Del Rio, Coral, Alonso-Villar, Olga (2010). Gender segregation in the Spanish labor market: An alternative approach. Social Indicator Research 98(2), 337-362

Dixon, Sylvia (2009). Who hires older workers? A first look at industry variations in the recruitment of mature workers. Statistics New Zealand (March 2009).

Duncan, Otis D., Duncan Beverly (1955). A methodological analysis of segregation indices. American Sociological Review 20(2), 210-217

Drews, Nils, Groll, Dominik, Jacobebbinghaus, Peter (2007). Programmierbeispiele zur Ausbereitung von FDZ Personendaten in STATA. FDZ Methodenreport, 6/2007

Drews, Nils (2008). Das Regionalfile der IAB-Beschäftigtenstichprobe 1975-2004. Handbuch-Version 1.0.3. FDZ Methodenreport, 2/2008

Dygalo, Natalya (2007). On unemployment duration and narrowing job opportunities at older ages. Economics Bulletin 10(21), 1-6

Eichhorst, Werner, Grienberger-Zinglerle, Maria, Konle-Seidl, Regina (2010). Activating 
labor market and social policies in Germany: From status protection to basic income support. German Policy Studies 6(1), 65-106

Eichhorst, Werner, Marx, Paul (2011). Reforming German labour market institutions: A dual path to flexibility. Journal of European Social Policy 21(1), 73-87

Falk, Susanne (2002). Geschlechtsspezifische und berufliche Segregation in Ostdeutschland zwischen Persistenz, Verdrängung und Angleichung: ein Vergleich mit Westdeutschland für die Jahre 1991-2000. Mitteilungen aus der Arbeitsmarkt- und Berufsforschung 35(1), 37-59

Feil, Michaela, Tillmann, Lisa, Walwei, Ulrich (2008). Arbeitsmarkt- und Beschäftigungspolitik nach der Wiedervereinigung. Zeitschrift für Sozialreform / Journal of Social Policy Research 54(2), 161-185

Fuchs, Johann, Söhnlein, Doris, Weber, Brigitte (2011). Projektion des Arbeitskräfteangebots bis 2050: Rückgang und Alterung sind nicht mehr aufzuhalten. IAB-Kurzbericht 16/2011

Heywood, John S., Ho, Lok-Sang, Wei, Xiangdong (1999). The determinants of hiring older workers. Evidence from Hong Kong. Industrial and Labor Relations Review 52(3), 444-459

Heywood, John S., Siebert, W. Stanley (2009). Understanding the labour market for older workers: a survey. IZA Discussion Paper 4033

Heywood, John S., Jirjahn, Uwe, Tsertsvadze, Georgi (2010). Hiring older workers and employing older workers. German evidence. Journal of Population Economics 23(2), 595-615

Hirsch, Barry T., Macpherson, David A., Hardy, Melissa A. (2000). Occupational age structure and access for older workers. Industrial and Labor Relations Review 53(3), 401-418 Humpert, Stephan, Pfeifer, Christian (2013). Explaining Age and Gender Differences in Employment Rates: A Labor Supply Side Perspective. Journal of Labour Market Research, 46(1), 1-17

Hutchens, Robert M. (1986). Delayed payment contracts and a firm's propensity to hire older workers. Journal of Labor Economics 4(4), 439-457

Hutchens, Robert M. (1988). Do job opportunities decline with age? Industrial and Labor Relations Review 42(1), 89-99

Hutchens, Robert M. (1991). Segregation curves, Lorenz curves and, inequality in the distribution of people across occupations. Mathematical Social Sciences 21(1), 31-51

Hutchens, Robert M. (1993). Restricted job opportunities and older worker. Mitchell, Olivia S. (Editor) As the workforce ages, ILR Press, Ithaca, New York, 81-102

Hutchens, Robert M. (2001). Numerical measures of segregation. Desirable properties and there implications. Mathematical Social Sciences 42(1), 13-29

Hutchens, Robert M. (2004). One measure of segregation. International Economic Review 45(2), 555-578

Hutchens, Robert M. (2007). Job opportunities for older workers: When are jobs filled with external hires? Yamaguchi, Mitoshi (Editor) Population change, labor markets and sustainable growth: Towards a new economic paradigm (Contributions to Economic Analysis 281), Emerald, 133-159

Hutchens, Robert M. (2012). Measuring Segregation when hierarchy matters. IZA Discussion Paper 6667

Ilmakunnas, Pekka, Ilmakunnas, Seija (2012). Age segregation and hiring of older employees: 
Low mobility revisited. Labour Institute for Economic Research Discussion Paper 273

James, David R., Taeuber, Karl E. (1985). Measures of segregation. Sociological Methodology 15, 1-32

Jenkins, Stephan P. (2006). HUTCHENS: Stata module to calculate the Hutchens 'square root' segregation index with optional decompositions by subgroups. Statistical Software Components S456601, Boston College Department of Economics

Kambourov, Gueorgui, Manovskii, Iourii (2008). Rising occupational and industry mobility in the united states: 1968-97. International Economic Review 49(1), 41-79

Kohn, Karsten, Antonczyk, Dirk (2011). The aftermath of reunification: Sectoral transition, gender, and rising wage inequality in East Germany. IZA Discussion Paper 5708

Koller, Barbara, Gruber, Hannelore (2001). Ältere Arbeitnehmer im Betrieb und als Stellenbewerber aus der Sicht der Personalverantwortlichen. Mitteilungen aus der Arbeitsmarkt- und Berufsforschung 34(4), 479-505

Lahey, Joanna N. (2008). Age, women and hiring. An experimental study. Journal of Human Resources 43(1), 30-56

Lazear, Edward P. (1979). Why is there mandatory retirement? Journal of Political Economy 87(6), 1261-1284

Lazear, Edward P. (1981). Agency, earnings profiles productivity and hours restrictions. American Economic Review 71(4), 606-620

Maetzke, Margitta, Ostner, Ilona (2010). The role of old ideas in the new German family policy agenda. German Policy Studies 6(3), 119-162

O`Brian, Martin (2010). Older male labour force participation in OECD countries: Pension reforms and "the reserve army of labour". International Labour Review 149(3), 239-259

Oi, Walter Y. (1962). Labor as a Quasi-Fixed Factor. Journal of Political Economy 70(6), 538-555

Ostner, Ilona (2010). Farewell to the family as we know it: Family policy change in Germany. German Policy Studies 6(1), 211-244

Pfeifer, Christian (2009). Adjustment of deferred compensation schemes, fairness concerns, and hiring of older workers. University of Lüneburg Working Paper Series in Economics 151 Pfeifer, Christian, Wagner, Joachim (2012). Age and gender composition of the workforce, productivity and profits: Evidence from a new type of data for German enterprises. University of Lüneburg Working Paper Series in Economics 232.

Pfeiffer, Friedhelm, Reuß, Karsten (2008). Age-dependent skill formation and returns to education. Labour Economics 15(4), 631-646

Ransom, Michael R. (2000). Sampling distribution of segregation indexes. Sociological Methods and Research 28(4), 454-475

Rhein, Thomas, Trübswetter, Parvati (2012). Occupational mobility and the change in the occupational structure in Britain and Germany, 1993-2008. Applied Economics Letters 19(7), 653-656

Scott, Frank A., Berger Mark C., Garen John E. (1995). Do health insurance and pension costs reduce the job opportunities for older workers? Industrial and Labor Relations Review 48(4), 775-791

Van Dalen, Hendrik P., Henkens, Kene, Schippers, Joos (2010). Productivity of older workers. 
Perceptions of employers and employees. Population and Development Review 36(2), 309-330

Vandenberghe, Vincent (2011). Boosting the employment rates of older men and women: An empirical assessment using Belgian firm-level data on productivity and labour costs. De Economist - Special Issue: Aging Workforce 159(2), 159-191

Watts, Martin (1998), Occupational gender segregation. Index measurement and econometric modeling. Demography 35(4), 489-496

Wichert, Laura, Wilke, Ralf A. (2012). Which factors safeguard employment? An analysis with misclassified German register data. Journal of the Royal Statistical Society: Series A, 175(1), 135-151

Zwick, Thomas (2012). Consequences of seniority wages on the employment structure. Industrial and Labor Relations Review, 65(1), 108-125

\section{Appendix}

Table A1: List of Occupations

\begin{tabular}{|l|l|}
\hline Nr. & Occupations: \\
\hline 1 & $\begin{array}{l}\text { Farmers / Winegrowers / Animal breeders / Fishermen / Managers in agriculture } \\
\text { and animal breeding / Agricultural engineers, agriculture advisers / Milkers } \\
\text { Family-member land workers, n.e.c./ Animal keepers and related occupations }\end{array}$ \\
\hline 2 & Land workers \\
\hline 3 & $\begin{array}{l}\text { Gardeners, garden workers } \\
\text { harden architects, garden managers / Florists / Forestry managers, foresters, }\end{array}$ \\
\hline 5 & $\begin{array}{l}\text { Miners / Mechanical, electrical, face workers, shot firers / Stone crushers / Earth, } \\
\text { gravel, sand quarries / Oil, natural gas quarries / Mineral prepairers, mineral } \\
\text { burners }\end{array}$ \\
\hline 6 & $\begin{array}{l}\text { Stone preparers / Jewel preparers / Stoneware, earthenware makers / Shaped brick, } \\
\text { concrete block makers }\end{array}$ \\
\hline 7 & $\begin{array}{l}\text { Ceramics workers / Frit makers / Hollow glassware makers / Flat glass makers / } \\
\text { Glass blowers (lamps) / Glass processors, glass finishers }\end{array}$ \\
\hline 9 & \begin{tabular}{l} 
Rubber makers, processors / Vulcanizes \\
\hline
\end{tabular} \\
\hline 4
\end{tabular}




\begin{tabular}{|c|c|}
\hline 10 & Plastics processors \\
\hline 11 & $\begin{array}{l}\text { Paper, cellulose makers / Packaging makers / Book binding occupations / Other } \\
\text { paper products makers / }\end{array}$ \\
\hline 12 & $\begin{array}{l}\text { Type setters, compositors / Printed goods makers / Printers (letterpress) / Printers } \\
\text { (flat, gravure) / Special printers, screeners / Copiers / Printer's assistants }\end{array}$ \\
\hline 13 & $\begin{array}{l}\text { Wood preparers / Wood moulders and related occupations / Wood products makers / } \\
\text { Basket and wicker products makers / }\end{array}$ \\
\hline 14 & Iron, metal producers, melter / Rollers / Metal drawers \\
\hline 15 & $\begin{array}{l}\text { Moulders, core makers / Mould casters / Semi-finished product fettlers and other } \\
\text { mould casting occupations }\end{array}$ \\
\hline 16 & $\begin{array}{l}\text { Sheet metal pressers, drawers, stampers / Wire moulders, processors / Other metal } \\
\text { moulders (non-cutting deformation) }\end{array}$ \\
\hline 17 & Turners / \\
\hline 18 & Drillers / Planers / Borers / Metal grinders / Other metal-cutting occupations \\
\hline 19 & Metal grinders \\
\hline 20 & $\begin{array}{l}\text { Metal polishers / Engravers, chasers / Metal finishers / Galvanisers, metal colourers } \\
\text { / Enamellers, zinc platers and other metal surface finishers }\end{array}$ \\
\hline 21 & $\begin{array}{l}\text { Welders, oxyacetylene cutters / Solderers / Riveters / Metal bonders and other metal } \\
\text { connectors }\end{array}$ \\
\hline 22 & $\begin{array}{l}\text { Steel smiths / Container builders, copper smiths and related occupations / Sheet } \\
\text { metal workers / Pipe, tubing fitters }\end{array}$ \\
\hline 23 & Plumbers \\
\hline 24 & Locksmiths, not specified / Building fitters / Sheet metal, plastics fitters \\
\hline 25 & Engine fitters \\
\hline 26 & Plant fitters, maintenance fitters \\
\hline
\end{tabular}




\begin{tabular}{|c|c|}
\hline 27 & Steel structure fitters, metal shipbuilders \\
\hline 28 & Motor vehicle repairers \\
\hline 29 & Agricultural machinery repairers / Aircraft mechanics / Precision mechanics \\
\hline 30 & Other mechanics / Watch-, clock makers \\
\hline 31 & Toolmakers \\
\hline 32 & $\begin{array}{l}\text { Precision fitters n.e.c. / Precious metal smiths / Dental technicians / Ophthalmic } \\
\text { opticians / Musical instrument makers / Doll makers, model makers, taxidermists }\end{array}$ \\
\hline 33 & Electrical fitters, mechanics \\
\hline 34 & Telecommunications mechanics, craftsmen \\
\hline 35 & $\begin{array}{l}\text { Electric motor, transformer fitters / Electrical appliance fitters / Radio, sound } \\
\text { equipment mechanics }\end{array}$ \\
\hline 36 & Electrical appliance, electrical parts assemblers \\
\hline 37 & Other assemblers \\
\hline 38 & Metal workers (no further specification) \\
\hline 39 & $\begin{array}{l}\text { Spinners, fibre preparers / Spoolers, twisters, rope makers / Weaving preparers / } \\
\text { Weavers / Tufted goods makers / Machined goods makers / Felt makers, hat body } \\
\text { makers / Textile processing operatives (braiders) }\end{array}$ \\
\hline 40 & $\begin{array}{l}\text { Cutters / Laundry cutters, sewers / Embroiderers / Hat, cap makers / Sewers, n.e.c. / } \\
\text { Other textile processing operatives / Textile dyers / Textile finishers }\end{array}$ \\
\hline 41 & Clothing sewers \\
\hline 42 & $\begin{array}{l}\text { Leather makers, catgut string makers / Shoemakers / Footwear makers / Coarse } \\
\text { leather goods finishers, truss makers / Fine leather goods makers / Leather clothing } \\
\text { makers and other leather processing operatives / Hand shoemakers / Skin } \\
\text { processing operatives }\end{array}$ \\
\hline 43 & Bakery goods makers / Confectioners (pastry) \\
\hline
\end{tabular}




\begin{tabular}{|c|c|}
\hline 44 & Butchers / Meat, sausage goods makers / Fish processing operatives \\
\hline 45 & Cooks / Ready-to-serve meals, fruit, vegetable preservers, preparers \\
\hline 46 & $\begin{array}{l}\text { Wine coopers / Brewers, maltsters / Other beverage makers, tasters / Tobacco goods } \\
\text { makers / Milk, fat processing operatives / Flour, food processors / Sugar, sweets, } \\
\text { ice-cream makers }\end{array}$ \\
\hline 47 & Bricklayers \\
\hline 48 & Concrete workers \\
\hline 49 & Carpenters / Scaffolds \\
\hline 50 & Roofers \\
\hline 51 & $\begin{array}{l}\text { Paviors / Road makers / Track layers / Explosives men (except shotfirers) / Land } \\
\text { improvement, hydraulic engineering workers / Other civil engineering workers }\end{array}$ \\
\hline 52 & Building labourer, general \\
\hline 53 & Earth movers / Other building laborers, building assistants, n.e.c. \\
\hline 54 & $\begin{array}{l}\text { Stucco workers, plasterers, rough casters / Insulators, proffers / Tile setters / } \\
\text { Furnace setter, air heating installers / Glaziers / Screed, terrazzo layers }\end{array}$ \\
\hline 55 & Room equippers / Upholsterers, mattress makers \\
\hline 56 & $\begin{array}{l}\text { Carpenters / Model, form carpenters / Cart wrights, wheelwrights, coopers / Other } \\
\text { wood and sports equipment makers }\end{array}$ \\
\hline 57 & Painters, lacquerers (construction) \\
\hline 58 & $\begin{array}{l}\text { Goods painters, lacquerers / Wood surface finishers, veneerers / Ceramics, glass } \\
\text { painters }\end{array}$ \\
\hline 59 & Goods examiners, sorters, n.e.c. \\
\hline 60 & Packagers, goods receivers, dispatchers \\
\hline 61 & Assistants (no further specification) \\
\hline
\end{tabular}




\begin{tabular}{|c|c|}
\hline 62 & $\begin{array}{l}\text { Generator machinists / Winding engine drivers, aerial rope way machinists / Other } \\
\text { machinists / Crane drivers / Earth moving plant drivers / Construction machine } \\
\text { attendants / Machine attendants, machinists' helpers / Stokers / Machine setters (no } \\
\text { further specification) }\end{array}$ \\
\hline 63 & Mechanical, motor engineers \\
\hline 64 & Electrical engineers \\
\hline 65 & Architects, civil engineers \\
\hline 66 & $\begin{array}{l}\text { Survey engineers / Mining, metallurgy, foundry engineers / Other manufacturing } \\
\text { engineers }\end{array}$ \\
\hline 67 & Other engineers \\
\hline 68 & $\begin{array}{l}\text { Chemists, chemical engineers / Physicists, physics engineers, mathematicians / } \\
\text { Building technicians }\end{array}$ \\
\hline 69 & Mechanical engineering technicians \\
\hline 70 & Electrical engineering technicians \\
\hline 71 & $\begin{array}{l}\text { Measurement technicians / Mining, metallurgy, foundry technicians / Chemistry, } \\
\text { physics technicians / Remaining manufacturing technicians }\end{array}$ \\
\hline 72 & Other technicians \\
\hline 73 & Foremen, master mechanics \\
\hline 74 & $\begin{array}{l}\text { Biological specialists / Physical and mathematical specialists / Chemical laboratory } \\
\text { assistants / Photo laboratory assistants }\end{array}$ \\
\hline 75 & Technical draughtspersons \\
\hline 76 & Wholesale and retail trade buyers, buyers / \\
\hline 77 & Salespersons \\
\hline 78 & $\begin{array}{l}\text { Publishing house dealers, booksellers / Druggists, chemists (pharmacy) / Pharmacy } \\
\text { aids / Service-station attendants }\end{array}$ \\
\hline
\end{tabular}




\begin{tabular}{|c|c|}
\hline 79 & Commercial agents, travelers / Mobile traders \\
\hline 80 & Bank specialists / Building society specialists \\
\hline 81 & $\begin{array}{l}\text { Health insurance specialists (not social security) / Life, property insurance } \\
\text { specialists }\end{array}$ \\
\hline 82 & Forwarding business dealers \\
\hline 83 & $\begin{array}{l}\text { Tourism specialists / Publicity occupations / Brokers, property managers / } \\
\text { Landlords, agents, auctioneers / Cash collectors, cashiers, ticket sellers, inspectors }\end{array}$ \\
\hline 84 & Railway engine drivers \\
\hline 85 & Railway controllers, conductors \\
\hline 86 & Motor vehicle drivers \\
\hline 87 & $\begin{array}{l}\text { Navigating ships officers / Technical ships officers, ships engineers / Deck seamen / } \\
\text { Inland boatmen / Other water transport occupations / Air transport occupations }\end{array}$ \\
\hline 88 & Post masters / Radio operators / Telephonists \\
\hline 89 & Postal deliverers \\
\hline 90 & Warehouse managers, warehouseman \\
\hline 91 & Transportation equipment drivers \\
\hline 92 & Stowers, furniture packers / Stores, transport workers \\
\hline 93 & Entrepreneurs, managing directors, division managers \\
\hline 94 & Management consultants, organizers / Chartered accountants, tax advisers \\
\hline 95 & $\begin{array}{l}\text { Members of Parliament, Ministers, elected officials / Senior government officials / } \\
\text { Association leaders, officials }\end{array}$ \\
\hline 96 & Cost accountants, valuers \\
\hline 97 & Accountants \\
\hline
\end{tabular}




\begin{tabular}{|c|c|}
\hline 98 & Cashiers \\
\hline 99 & Data processing specialists \\
\hline 100 & Office specialists \\
\hline 101 & Stenographers, shorthand-typists, typists \\
\hline 102 & Data typists \\
\hline 103 & Office auxiliary workers \\
\hline 104 & $\begin{array}{l}\text { Factory guards, detectives / Watchmen, custodians / Soldiers, border guards, police } \\
\text { officers / Firefighters / Safety testers / Chimney sweeps / Health-protecting } \\
\text { occupations / Arbitrators / Judicial administrators / Legal representatives, advisers / } \\
\text { Judicial enforcers }\end{array}$ \\
\hline 105 & Doormen, caretakers \\
\hline 106 & Domestic and non-domestic servants \\
\hline 107 & Journalists / Interpreters, translators / Librarians, archivists, museum specialists \\
\hline 108 & $\begin{array}{l}\text { Musicians / Artists' agents / Visual, commercial artists / Scenery, sign painters / } \\
\text { Artistic and assisting occupations (stage, video and audio) / Interior, exhibition } \\
\text { designers, window dressers / Photographers / Performers, professional sportsmen, } \\
\text { auxiliary artistic occupations }\end{array}$ \\
\hline 109 & Physicians / Dentists / Veterinary surgeons / Pharmacists \\
\hline 110 & Non-medical practitioners / Masseurs, physiotherapists and related occupations \\
\hline 111 & Nurses, midwives \\
\hline 112 & Nursing assistants \\
\hline 113 & Dietary assistants, pharmaceutical assistants / Medical laboratory assistants \\
\hline 114 & Medical receptionists \\
\hline 115 & Social workers, care workers / Work, vocational advisers \\
\hline
\end{tabular}




\begin{tabular}{|c|c|}
\hline 116 & Home wardens, social work teachers \\
\hline 117 & Nursery teachers, child nurses \\
\hline 118 & $\begin{array}{l}\text { University teachers, lecturers at higher technical schools and academies / } \\
\text { Gymnasium teachers / Technical, vocational, factory instructors / Music teachers, } \\
\text { n.e.c. / Sports teachers / Other teachers }\end{array}$ \\
\hline 119 & Primary, secondary (basic), special school teachers \\
\hline 120 & $\begin{array}{l}\text { Economic and social scientists, statisticians / Humanities specialists, n.e.c. / } \\
\text { Scientists n.e.c. / Nursing staff / Ministers of religion / Members of religious orders } \\
\text { without specific occupation / Religious care helpers }\end{array}$ \\
\hline 121 & Hairdressers / Other body care occupations \\
\hline 122 & Restaurant, inn, bar keepers, hotel proprietors, catering trade dealers \\
\hline 123 & Waiters, stewards \\
\hline 124 & Others attending on guests \\
\hline 125 & $\begin{array}{l}\text { Housekeeping managers / Consumer advisers / Other housekeeping attendants / } \\
\text { Employees by household cheque procedure }\end{array}$ \\
\hline 126 & Laundry workers, pressers / Textile cleaners, dyers and dry cleaners \\
\hline 127 & Household cleaners \\
\hline 128 & Glass, buildings cleaners \\
\hline 129 & $\begin{array}{l}\text { Street cleaners, refuse disposers / Vehicle cleaners, servicers / Machinery, container } \\
\text { cleaners and related occupations }\end{array}$ \\
\hline $130 *$ & $\begin{array}{l}\text { Non-agricultural family assistants, n.e.c. / Trainees with recognized training } \\
\text { occupation still to be specified / Interns, unpaid trainees with recognized training } \\
\text { occupation still to be specified / Workforce (job seekers) with occupation still to be } \\
\text { specified }\end{array}$ \\
\hline * & excluded because of insecure job information \\
\hline
\end{tabular}


Source: IABS 1975-2004. 